\title{
VLIV VĚKOVÉHO USPOŘÁDÁNÍ TŘÍD NA EDUKACI V MATEŘSKÝCH ŠKOLÁCH
}

\author{
THE INFLUENCE OF THE CLASSROOM \\ AGE ARRANGEMENT ON PRESCHOOL \\ EDUCATION
}

\author{
ZORA SYSLOVÁ, \\ EVA NOVÁKOVÁ, \\ VERONIKA NAJVAROVÁ
}

\begin{abstract}
Abstrakt
Přebledová studie si klade za cíl żmapovat výzkumy zamèrèné na problematiku věkově heterogennich a homogennich trìd v materskeých školách. Této oblasti neni v reském predškolnim vadèláváni vènován žádný relevantni výžkum, prestože se s povinnou prèš̌kolni docházkou (od roku 2017) zvýšila četnost diskusi o vhodnosti heterogenního usporádáni tríd. Studie využivá 14 časopiseckeych studii a dvou kapitol $v$ monografiich ze šesti zemí, aby odpovédèla na následujicí otárky: (1) Jaké cíle byly ve studiích sledovány? (2) Jaká podstatná zjišténi a závèry z tèchto studii vyplynuly? Shrnuti nálezũ z vybraných studii naznacuji smèr, jakým by se mohl ubirat výzkeum predškolního vzděláváni v českém prostředi mateřrských škol.
\end{abstract}

\section{Klíčová slova}

beterogenni trúdy, homogenni trídy, prédškolni vąéláváni, prébledová studie

\begin{abstract}
The main aim of this review study is to map research that was conducted on mixed-age and same-age preschool classrooms. In the Czech Republic, very little attention has been dedicated to these settings, although after the 2017 implementation of the compulsory preschool year, more attention and discussion is being paid to this research field. A total of 14 studies and 2 chapters from 6 countries were selected and analyzed to answer following questions: (1) What aims are pursued in these studies? and (2) What are the main results of the analyzed studies? A summary of the research findings indicates the orientation of possible preschool school level research in the Caech Republic.
\end{abstract}

\section{Keywords}

mixed-aged classrooms, same-age classrooms, preschool education, review study 


\section{Úvod}

Předškolní vzdělávání se stalo významnou součástí vzdělávacích systémů všech vyspělých zemí světa a o jeho kvalitě se diskutuje např́íc mezinárodními organizacemi, jakými jsou např. OECD, UNESCO, Evropská komise apod. V diskusi panuje shoda na aspektech kvality především v důrazu kladeném na vyvážený kognitivní a socioemoční rozvoj nejmladších dětí. To je pro předškolní vzdělávání v České republice jedna z největších výzev kurikulární reformy, nebot’ v Programu výchouné práce pro jesle a mateřské školy (1984) jako kurikulu jednotného pojetí př̀edškolního vzdělávání v totalitním režimu dominoval především kognitivní rozvoj. Tento program byl postaven na vývojových (nikoli individuálních) specificích dětí předškolního věku a všechny metodiky byly sestaveny podle věkových kategorií, tzn. vymezovaly úkoly pro učitelku a plánované činnosti zvlášt' pro děti 3-4leté, 4-5leté, 5-6leté. V historickém kontextu tedy byla heterogenita spíše výjimkou. Heterogenní tř́ídy vznikaly pouze $\mathrm{v}$ případě jednotř́ídních mateřských škol nebo tzv. malotřídních škol.

Prvním programem, který po revoluci v roce 1989 upozornil na důležitost socioemočních aspektů $\mathrm{v}$ rozvoji dítěte předškolního věku, byl program Podpory źdraví v mateřské škole (Havlínová, 1995). Pro naplnění tohoto požadavku považuje za nezbytné věkově heterogenní uspořádání tř́i mateřských škol, o němž se vyjadřuje ve smyslu, že: „Čím větší je věkový rozdíl mezi dětmi, tím bohatší a pestřejší jsou kontakty mezi nimi, tím více sociálních rolí a strategií si děti mohou osvojit, tím více př́ležitostí mají $\mathrm{k}$ přirozené nápodobě, k rozvoji jazyka a komunikace“ (Havlínová et al., 2000, s. 42).

Rámcový vądèlávaci program pro predškolni vadèláváni (RVP PV, 2018), který vešel v platnost $\mathrm{v}$ roce 2004, klade důraz na osobnostní rozvoj dítěte, tedy na vyvážený kognitivní a socioemoční rozvoj, jak potvrdila také mezinárodní srovnávací studie (Taguma et al., 2012). RVP PV uvádí, že „do tř́d je možno zařazovat děti stejného či různého věku a vytvářet tř́́dy věkově homogenní či věkově heterogenní" (2018, s. 6). Nejde však o požadavek, ale spíše o možnost takto tvořit tř́idy mateřských škol. Vyvstává však otázka, jak je v praxi mateřských škol požadavek na vyvážený kognitivní a socioemoční rozvoj realizovaný. Současně se nabízí otázka, jakému uspořádání dávají mateřské školy přednost. O uspořádání tříd mateřských škol nenajdeme žádné statistické údaje. Z hospitací prováděných Českou školní inspekcí vyplynulo, že v roce 2019 bylo z celkového počtu 4103 navštívených tříd 1112 věkově smíšených, respektive pro děti od tři do šesti let věku. Můžeme se tedy domnívat, že jde asi o čtvrtinu z celkového počtu tříd v České republice. 
V zahraničí můžeme sledovat polemiku o výhodách a nevýhodách heterogenního uspořádání tř́d již řadu let. Nejčastěji se pojí s argumenty, že homogenní seskupování dětí podle jednoho kritéria (věku) nevytváří skupiny, které by byly homogenní v dalších kritériích (dispozice dětí, jejich zájmy, zkušenosti, potřeby, rodinné zázemí atd.), která jsou relevantní pro vzdělávání (Goodlad \& Anderson, 1987). To je v souladu s výrokem Katzové et al. (1990, s. 10), která ř́ká, že „ačkoli se lidé obvykle nerodí v jednom vrhu, trváme na tom, že tak budou učeni““.

Naší snahou je proto identifikovat, jaká zjištění ohledně uspořádání tříd přinášejí zahraniční studie, zejména $\mathrm{v}$ souvislosti s rozvojem dítěte a v souvislosti s náročností práce pro učitele.

\section{Teoretická východiska}

Pro zkoumání heterogenních tř́d lze najít teoretická východiska v práci Piageta, Bandury a Vygotského, kteří byli přesvědčeni, že prostředí ovlivňuje dítě, jeho kognitivní i sociální rozvoj (Bandura, 1986; Inhelder \& Piaget, 1958; Vygotskij, 1978). Harmon (2001), s odkazem na práci Piageta, poznamenal, že zásadní pro rozvoj dítěte jsou interakce s dalšími dětmi různé vývojové úrovně, které mohou vést ke „kognitivnímu konfliktu“. Při něm jsou děti vystaveny zvažování alternativních úhlů pohledu. Konflikty stimulují dychtivost dětí učit se a podporují je v rozvíjení pozitivního vztahu ke škole (Brown \& Palinscar, 1986; Reeve \& Brown, 1985; Stone, 1998; Veenman, 1996). Tyto konflikty mohou současně představovat tzv. „lešení“ (scaffolding) (Bruner, 1978), které podporuje rozvoj dítěte v tzv. „zóně nejbližšího vývoje“. Vygotskij (1978) tvrdí, že při interakci v zóně nejbližšího vývoje může dítě interiorizovat informace poznatky, které se právě naučilo. Zónu nejbližšího vývoje lze vysvětlit jako vzdálenost mezi současnou úrovní vývoje, která umožňuje dítěti řešit problém samostatně, a pokročilou úrovní potenciálního vývoje, kterou dítě řeší spoluprací s jiným dítětem nebo dospělým. Bandura (1986) naproti tomu zdůrazňuje učení pozorováním v teorii sociálního učení. Sledování starších dětí a interakce s nimi podle něj pomáhají malým dětem zapojit se např. do složitější hry či dalších činností.

Při vymezení pojmu „,heterogenní“ vycházíme z Rathbonovy (1993, s. 64) definice, která ř́ká, že „heterogenní tř́ída je ta, ve které jsou děti různého věku a stupně vývoje společně“, a $\mathrm{k}$ učení využívá právě velké různorodosti znalostí uvnitř skupiny. Také další definice, které můžeme najít ve starší literatuře (např. Blasco et al., 1993; Kasten \& Clarke, 1993; McClellan \& Kinsey, 1994; Slavin, 1987; Whiting, 1983), jsou obdobné. Všechny se zaměřuí na úmyslné seskupování dětí alespoň dvou věkových skupin za účelem efektivnějšího vzdělávání dětí, které využívá různorodosti dětí, co se týká úrovně 
dosažených výsledků a stylů učení. Př́stup $\mathrm{k}$ dětem je $\mathrm{v}$ těchto třídách založen na ocenění rozmanitosti skupiny, na tom, že děti nejsou srovnávány, ale pozornost je zaměřena na jejich individuální pokroky. Za důležité se v těchto třídách považuje sdílení zkušeností a vytváření jedinečné (individuální) struktury znalostí (Katz et al., 1990; Miller, 1994; Politano \& Davies, 1994; Rice \& Shortland-Jones, 1999). Podle Bredekampové (1987) se školy, které vytvářejí vhodné podmínky a př́ležitosti $\mathrm{k}$ učení pro děti v souladu s jejich vývojovými a individuálními potřebami, řadí mezi nejkvalitnější školy. Tyto školy jsou flexibilní v jejich očekáváních, kdy a jak dítě dosáhne určitých kompetencí.

Mnozí autoři odborných studií (Bacharach et al., 1995; Blackmore, 1996; Bredekamp, 1987; Katz et al., 1990) považují věkově heterogenní tř́dy vzhledem $\mathrm{k}$ výše uvedeným charakteristikám za vhodné prostředí pro vzdělávání dětí předškolního věku a popisují jej jako protiklad prostředí homogenního, které ze své podstaty neodpovídá potřebám většiny dětí raného věku. V homogenních tř́ídách je podle nich důraz kladen především na rozvoj kognitivních dovedností. Věkově heterogenní třídy tvoří „,vhodnou vzdělávací alternativu, která optimalizuje individualizované vzdělávání podle potřeb každého dítěte“ (Tercek, 1997, s. 20).

Jak zdůraznila Katzová et al. (1990), ve smíšené třídě učitelé lépe odolávají trendu vzdělávat děti způsoby charakteristickými pro vyšší stupně vzdělávání. Tento kolektiv autorů také zjistil, že věkově heterogenní tř́ídy nejsou samy o sobě „katalyzátorem“ lepších kognitivních a socioemočních výsledků v rozvoji dítěte. Jde spíše o implementaci konkrétních strategií, které podporují výměnu zkušeností mezi staršími a mladšími dětmi. Harmon (2001) k tomu dodává, že starší děti mají prospěch z převzetí role „experta“ nebo „poradce“ tím, že získávají sebevědomí a sebeúctu, ale také prohlubují svoje znalosti tím tak, že „radí “ mladším dětem. V tomto ohledu se v roce 1987 vyjádřila také americká Národní asociace pro vzdělávání malých dětí (NAEYC). Byla znepokojená zvýšeným důrazem na kognitivní rozvoj v předškolních vzdělávacích programech. Asociace vydala doporučení, v němž klade důraz na vytváření bezpečného a pečujícího prostředí, které se přizpůsobuje potřebám dětí a jež podporuje fyzický, socioemoční a kognitivní rozvoj malých dětí (NAEYC, 1987). Za jeden z aspektů kvalitního předškolního vzdělávání považuje věkově heterogenní uspořádání tř̌íd $\mathrm{v}$ předškolních zařízeních.

Koncept věkové heterogenity můžeme najít jako důležitý aspekt vzdělávání také v programech Marie Montessori či waldorfské pedagogiky. Výzkumně podložená pozitivní zjištění o vlivu věkově heterogenní skupiny na hru uvádí i Př́hoda (1967). Některé zahraniční programy, stejně jako český Program podpory zdravi v materskeé šoole (Havlínová et al., 2000, 2006, 2008), také považují heterogenitu za důležitý aspekt rozvoje socioemočních dovedností. 
V zahraničí je to např. program The Incredible Years (Webster-Stratton, 2012), který si klade za cíl podporovat dětskou schopnost učit se sledováním druhých (sociální učení) a usměrňováním dětského chování v kontextu pozitivního vztahu učitele a dítěte (pomocí pochval, jasných př́íkazů a posilováním pozitivního chování místo upozorňování na negativní).

Uvažujeme-li o heterogenním uspořádání tříd $\mathrm{v}$ mateřské škole jako o jednom z důležitých aspektů individualizace a vyváženého kognitivního a socioemočního rozvoje, pak je namístě ptát se, proč není pro vzdělávání dětí v mateřských školách toto uspořádání požadováno či alespoň doporučováno. Sledujeme-li diskuse o předškolním vzdělávání at' již na odborné úrovni či v rámci mediálních kampaní, tomuto tématu byla v České republice věnována jen minimální pozornost. Na teoretické úrovni lze zmínit např́ḱlad Havlovou (2012) nebo Kot’átkovou (2014). Dílčí výzkumy pak můžeme najít $\mathrm{v}$ závěrečných pracích studentů vysokých škol. Z jejich zjištění vyplývá kupř́kladu neopodstatněnost obav, že by heterogenní tř́dy hưře připravovaly děti na vstup do základní školy (Srbová, 2011; Velíšková, 2014). Nejčastěji zmiňovaným negativem heterogenních tř́d je pak podle těchto výzkumů náročnost př́pravy pro učitele (Luňáková, 2008; Sajbotová, 2016; Svobodová, 2011).

Kromě nedostatečného výzkumného zmapování této problematiky v České republice můžeme najít také jistou diskrepanci při vyjasňování pojmu „heterogenní trrída“. V Pedagogickém slovniku je tento pojem definován jako „tř́ída složená ze žáků stejného věku bez ohledu na jejich schopnosti a učební předpoklady“ (Průcha et al., 2013, s. 90). Na vyšších stupních školy je heterogenita vnímána nikoli z hlediska věku, ale spíše schopností dětí. Rámcový v₹dèlávaci program pro predškeolni vzdéláváni (2018) používá pojmy věkově heterogenní a věkově homogenní, čímž upřesňuje heterogenitu směrem $\mathrm{k}$ vývojovým schopnostem dětí. Tak může docházet $\mathrm{k}$ problematickému chápání specifik heterogenních tř́d mateřských škol především u učitelů 1. tříd ZŠ, kteří bezprostředně navazují na předškolní vzdělávání.

Toto označení „věkově heterogenní“ je pak v souladu s anglickým označením mixed-age (věkově smíšená), popřípadě multi-age (vícevěková) či nongraded-classroom (netříděná tř́ida).

To vše nás přivedlo k potřebě ukázat, jaká zjištění přinášejí aktuální zahraniční výzkumy věnující se problematice věkově heterogenních tříd.

\section{Metodologie}

Cílem přehledové studie je nabídnout čtenáři pohled na zahraniční výzkumy zaměřené na zkoumání výhod heterogenních tříd či jejich porovnání s výsledky vzdělávání v homogenních tř́ídách mateřských škol, respektive insti- 
tuce určené pro děti předškolního věku. ${ }^{1}$ Jde o tzv. literární přehledovou studii (Mareš, 2013), která hledá odpověd' na otázku: Co zjistila dosavadní literatura o výhodách a nevýhodách heterogenních tříd? Zpracování přehledové studie bylo vedeno otázkami: (1) Jaké cíle byly ve studiích sledovány? (2) Jaká podstatná zjištění a závěry z těchto studií vyplynuly?

Rešerše provedl odborný pracovník knihovny Pedagogické fakulty Masarykovy univerzity. ${ }^{2}$ Jednalo se o studie vydané v letech 2000-2020. Zadání odpovídalo 47 studií. Pro další práci s textem byly vybrány pouze ty, které zkoumaly sledovaný jev empiricky. Vyřazeny byly abstrakty a metodické a teoretické studie. Celkem bylo analyzováno 14 časopiseckých studií a dvě kapitoly v monografii. Jedná se o anglicky psané texty, což můžeme považovat za limit přehledové studie, nebot' se nejedná o zahraniční studie $\mathrm{v}$ širokém slova smyslu.

\section{Výsledky přehledové studie}

Studie, se kterými jsme pracovaly, pocházely ze Spojených států amerických (9), Austrálie (2), Turecka (2), Číny (1), Nizozemí (1) a Velké Británie (1). Následující text je organizován podle výše uvedených výzkumných otázek.

\section{Jaké cíle byly $v$ analyzovaných studiuch sledovány}

Cíle studií a s nimi související okruhy výzkumných otázek v našem výběru se zaměřují na problematiku heterogenních a homogenních tříd mateřské školy z různého úhlu pohledu. Můžeme je rozdělit do čtyř oblastí. Uvádíme je v následujícím přehledu. Některé studie sledují více cílů, spadají proto do více oblastí současně:

A. Studie, které pohlížejí na uspořádání tříd z hlediska potenciálu optimálního socioemočního a kognitivního rozvoje dítěte.

B. Studie zaměrující se na problematiku heterogenních a homogenních tříd vzhledem $k$ činnosti učitele mateřské školy (jeho př́pravy a realizace aktivit ve tř́ídé).

V zahraničí existuje řada institucí určených pro děti předškolního věku: tedy děti od narození až po vstup do povinného primárního vzdělávání (ISCED 0). Podrobně se touto problematikou zabývá např. Syslová et al. (2014).

2 Rešerše byly provedeny se zadanými klíčovými slovy: „mixedage“, „multiage“, „early childhood“, „preschool“, „kindergarten“ v databázích Knihovny.cz, Pro Quest humanities, Scopus, Theses.cz, Web of Science Core Collection a metadatabázích elektronických zdrojů MU: Muni Discovery. 
C. Studie věnované názorům rodičů na zařazení jejich dítěte do tř́́dy s heterogenním nebo homogenním uspořádáním.

D. Studie, které se soustřed’ují na podchycení změn po zavedení intervence určitého typu: ve vztahu k dítěti nebo učiteli.

$\mathrm{V}$ první skupině obecně zaměřené na potenciál rozvoje dítěte (A) považujeme za klíčovou studii Ansariové (2017). Zaměřila se na hledání odpovědi na otázku: Jaká je současná prevalence heterogenních a homogenních tříd mateřských škol a jaké vlastnosti je odlišují? Patrný je důraz na komplexnější pohled související s akademickým úspěchem dětí, jejich výkonovou funkcí a socioemočním vývojem. Sledovala, jaké jsou výsledky pětiletých dětí $\mathrm{z}$ heterogenních tř́íd $\mathrm{v}$ porovnání $\mathrm{s}$ výsledky pětiletých dětí $\mathrm{z}$ homogenních tř́d a jaké mechanismy ovlivňují v heterogenní tř́idě školní úspěch pětiletých dětí.

Další studie byly zacíleny na heterogenní a homogenní tř́idy z hlediska schopností a vlastností osobnosti, které toto uspořádání v dětech rozvijí, na vliv věku na výsledky učení dítěte (Cascio et al., 2007). Zkoumání vlivu věku na vývojové charakteristiky dětí a výsledky učení dítěte v prostředí heterogenní třídy sledoval také výzkum Okutanové et al. (2014). Autoři rozvíjejí myšlenku, že pro děti, které vykazují pokroky různé úrovně v různých oblastech vývoje, by učení nemělo být omezeno pouze na jeden výukový model, což autoři považují za jeden z nejpřesvědčivějších argumentů pro heterogenní třídy. Učitelovy zkušenosti a jeho vzdělání jako faktory, které mohou ovlivňovat spojení mezi věkovou kompozicí tř́ídy a růstem znalostí a rozvoje dětí, sledovala studie Purtellové a Ansariové (2018).

Jiné studie pohlížející na potenciál rozvoje dítěte se zaměřují na konkrétní otázky související s jeho socializací. Zkoumají vliv složení tř́́dy na strategie emocionální regulace u předškolních dětí v souvislosti se způsobem vyjadřování emocí matky a vrstevníků (Hu et al., 2016). Zjišt’ují, zda se v heterogenním uspořádání budují lépe základy přátelství, zda heterogenní uspořádání působí pozitivně na sourozenecké vztahy, na zlepšení podmínek v mateřské škole, snížení soutěživosti a agresivity mezi dětmi, zda prostředí heterogenní třídy podporuje děti v objevování a vyjadřování se skrze různé způsoby komunikace, jako je vizuální umění nebo hudba. Jak kontext aktivit (např́íklad povědomí o přírodě) ovlivňuje dětské dotazování a jak učitel poskytuje podporu pro dotazování a intersubjektivitu ${ }^{3} \mathrm{v}$ různých aktivitách, sledovala Lanphearová (2016). 
Další cíle, které si autoři studií kladou, se zaměrují na obsahovou stránku rozvoje dětské osobnosti, na rozvoj pregramotnosti dětí v jednotlivých oblastech předškolního vzdělávání. Soustřed’ují se na to, jaké jsou hlavní efekty složení heterogenní tř́ídy v této oblasti, jak se promítnou do výkonu dětí, které stráví dva roky od tř́ let v heterogenní třídě, zda stejný učitel ve tř́iě ovlivní rané dětské výsledky učení a zda „utlumí“ či zvýrazní efekt heterogenní třídy. Zjišstují také, jestli jsou děti z heterogenních trríd lépe připraveny na vstup do základní školy (Ansari \& Purtell, 2018) či zda a v jaké míře vytváří heterogenní třída vhodné prostředí pro rozvoj čtenářské pregramotnosti (jazyka, řeči) a matematické pregramotnosti - geometrických a kvantitativních představ (Wood \& Frid, 2005). Další studie se zaměrovaly na to, jak se formuje skupina a rozvíjí osobnost dítěte díky kooperativnímu př́stupu s využitím různých uměleckých postupů (multimodel artsapproach), který přináší dítěti sociální i umělecké benefity (Barton \& Baguley, 2014).

Druhou skupinu výzkumů zaměřenou na činnost učitele materské školy (B) prezentují studie, $v$ nichž cíle a výzkumné otázky směřují k několika okruhům problémů. Názory učitelů mateřských a základních škol na vzdělávání ve věkově heterogenních skupinách, na vnímání přínosu a rizik věkově heterogenního uspořádání pro rozvoj dítěte, na zkušenosti učitelů s rozdílným věkovým uspořádáním trríd a na to, jak učitelé přizpůsobují svoji pedagogickou činnost danému uspořádání (Ansari \& Purtell, 2018; Bailey et al., 2016; Ertürk-Kara, 2018). Do této skupiny autorů lze zařadit i Helmerhorstovou et al. (2019), kteří pracovali ve svém výzkumu s pojmem mind-mindedness. Rozumí jím označení pro schopnost pečující osoby vidět a zacházet s dítětem jako s osobou s nezávislými myšlenkami a pocity. Sledovali míru všímavosti učitele k mysli dětí ve vztahu k různým proměnným, které souvisejí s osobností učitele (jeho vzděláním, délkou praxe) a dalšími objektivními faktory (počet dětí na učitele ve tř́dě, věkové uspořádání třídy).

Reprezentantem třetí skupiny analyzovaných studií věnované názorům rodičů (C) na zařazení jejich dítěte do heterogenní tř́dy je výzkum Teszenyiové a Heveyové (2015). Zaměřily se na otázku, jaké jsou klíčové faktory (věková skupina, umístění školy nebo pedagog) ovlivňující rozhodnutí rodičů při výběru mateřské školy v Mad’arsku a jak jsou rodiče se svým rozhodnutím pro heterogenní nebo homogenní tř́du spokojeni. Hledání shody či rozdílů $\mathrm{v}$ názorech učitelů a rodičů na vzdělávání dítěte $\mathrm{v}$ heterogenní tř́dě je také jedním z cílů výzkumu Baileyho et al. (2016).

Podchycení změn, které byly zjištěny po zavedení intervence určitého typu (at' už v dosahované úrovni dětí či ve změnách $\mathrm{v}$ profesní zdatnosti učitele mateřské školy) jsou cíli čtvrté skupiny studií (D). Výzkumně byly analyzovány programy na podporu dětí Head Start, který je největším federálně financovaným programem $\mathrm{v}$ USA pro děti z rodin s nízkým př́ijmem, zaměřeným na podporu vzdělávání dětí, rozvoj jejich kognitivních a sociálních 
dovedností prostřednictvím posilování sociálních interakcí ve třídě (Bell et al., 2013) a programy The Incredible Years, PATHS, Mind-play (Hsueh et al., 2014). Program The Incredible Years má podporovat socioemoční rozvoj dětí. Učitel je veden $\mathrm{k}$ vytváření podmínek a př́ležitostí, které podporují dětskou schopnost učit se sledováním druhých (sociální učení) a k usměrňování dětského chování v kontextu pozitivního vztahu učitele a dítěte pomocí pochval a posilování pozitivního chování. Program PATHS se snaží o zvyšování socioemočního rozvoje pomocí aktivit zaměřených na dětské pochopení emocí a dovednosti $\mathrm{k}$ řešení problémů za pomoci učitelova vzoru a podpory. Program Mind-play vyžaduje změnu režimu dne a vymezení větších časových bloků pro podporu dětské hry a námětové hry.

Další výzkum (Ansari \& Pianta, 2018) sledoval, zda je či není program profesního rozvoje učitelů mateřských škol efektivní v podmínkách heterogenních tř́íd v USA. My Teaching Partner (MTP) je program profesního rozvoje zaměřený na koučinkovou intervenci, který poskytuje učitelům znalosti, schopnosti a strategie, jak pracovat $\mathrm{v}$ interakci s dětmi. V programu jsou využívána videa, která učitelé natáčí ve své trrídě a následně rozebírají s koučem.

\section{Jaká podstatná zjistèní a závéry ze studii vyplynuly}

Následující text je veden ve shodě s cíli, jež si autoři analyzovaných studií stanovili a které jsme identifikovaly $\mathrm{v}$ přehledu uvedeném $\mathrm{v}$ předchozí kapitole. Hlavní zjištění výzkumu byla uváděna explicitně, některé podnětné informace vztahující se ke sledovanému tématu však byly obsaženy také v dílčích souvisejících výstupech. Nelze z nich vyvodit závěry, které by jednoznačně preferovaly jedno z možných uspořádání tř́́dy. Záleží na konkrétních, pregnantně formulovaných výzkumných cílech autorů i na interpretaci jejich zjištění v kontextu širšího rámce obecně pedagogických, pedeutologických a didaktických, sociálních, ekonomických a politických souvislostí.

Významnou představitelkou výzkumného proudu, studujícího potenciál optimálního socioemočního a kognitivního rozvoje dítěte v různém uspořádání tř́́dy (A), také $z$ pohledu jeho připravenosti na vstup do základní školy, je Ansariová (2017). V heterogenní tř́dě strávily děti méně času v hromadných a skupinových aktivitách, ale denně o tři hodiny více času při individuálních a na dítětem vybraných aktivitách. Menší rozsah činností než u dětí z homogenní třídy byl věnován rozvoji jazyka a předmatematických představ. Děti dosahovaly horších výsledků v předmatematické gramotnosti a čtení, v rozvoji jazyka a gramatiky, ve výkonových funkcích a externalizujícím chování. Přisuzuje to skutečnosti, že děti dostávaly méně učitelem řízených instrukcí. V sociálním chování se neprojevovaly lépe ani hủre než děti z homogenních tříd. 
V další studii uvádějí Ansariová a Purtellová (2018), že děti, které byly z homogenní tř́dy přesunuty do heterogenní, dosahovaly horších výsledků v předmatematické gramotnosti a ve čtení než děti, které byly přesunuty z heterogenní tř́idy do homogenní. Pokud byl v heterogenní tř́ídě zaznamenán vyšší podíl mladších dětí, starší děti vykazovaly menší pokroky ve čtení a matematice. Děti, které v druhém roce pobytu v mateřské škole přešly do třídy s větším poměrem stejně starých dětí, dosahovaly lepších výsledků než děti, které ve smíšené třídě zůstaly.

Uvedené skutečnosti naznačující slabší výsledky dětí v heterogenní tř̌idě mohou podle autorek pramenit $z$ nedostatečné připravenosti učitelů na specifika práce $\mathrm{v}$ tomto typu uspořádání. Učitelé mohou mít tendenci přizpůsobit svoji práci mladším dětem, což je pro starší a vyspělejší děti nevýhodné. Ze svého výzkumu autorky dále vyvodily závěr, že je třeba více dbát na způsob, jakým jsou děti do tř́d umist’ovány, a také na přípravu a vzdělávání učitelů pro práci v heterogenní tř́idě.

Zjištění však nejsou jednoznačná. K poněkud odlišným závěrům vztahujícím se k pozitivním či negativním stránkám heterogenního a homogenního uspořádání došli Casciová et al. (2007). Zjistili, že mladší děti, které byly ve třídě se staršími, vykazovaly lepší výsledky i na základní škole po osmi letech. U dětí se dokonce zvyšuje šance uspět při přijímacích zkouškách na vysokou školu. Tento benefit se zdá být menší pro chlapce a pro děti z rodin s vyšším příjmem i vzhledem k většímu výskytu odkladů vstupu do školy u této skupiny. Starší děti mohou být zase více sebevědomé a motivované ke vstupu do školy díky jejich postavení ve tř́ídě.

Metoda inquiry-based guidance založená na dotazech, na uplatnění otevřených otázek, rozvijejících dětskou zvídavost a vedoucích $\mathrm{k}$ řešení problémů (viz Ermeling, 2010; Gerde et al., 2013), byla použita ve studii Lanphearové (2016). Její výzkum byl zaměřen na komunikaci a intersubjektivitu jako nástroje socioemočního rozvoje $\mathrm{v}$ mateřských školách inspirovaných specifickým prrístupem „Reggio Emilia“" kolem nich prostřednictvím různých způsobů komunikace, jako je vizuální umění nebo hudba (Edwards et al., 2012). Ve výzkumu Lanphearové (2016) učitelky méně zasahovaly do objevitelských aktivit, vytvářel se tím větší prostor pro vzájemnou komunikaci mezi dětmi. Často se tak dělo ve smíšených skupinách, v nichž se starší děti ujaly vedení a vykazovaly i pokročilejší úroveň dotazování. V rámci intersubjektivity byla zkoumána rovněž frekvence a trvání určitého typu chování. Nejčastěji se objevoval vzájemný dotek a jiné

Název projektu, který vznikl po 2. světové válce, odkazuje na jeho italský původ. 
pozitivní emoce, povzbuzení a pomoc u vyjadřovacích aktivit (uměleckých), mnohdy se při něm spontánně vytvářely dvojice dětí stejného věku. To poskytovalo dostatek možností projevovat vlastní city, sdělovat citové dojmy a prožitky a hovořit o nich.

Z premisy, že pro děti, které vykazují různé pokroky v různých vývojových oblastech, by učení nemělo být omezeno pouze na jeden vzor, vychází výzkum Okutanové et al. (2014). Rozmanitost smíšených tř́d je bohatým stimulem, protože každé dítě má šanci najít si způsob učení vhodný pro svoji úroveň. Při hledání odpovědi na otázku, zda se liší vývojové charakteristiky dětí $\mathrm{v}$ závislosti na umístění $\mathrm{v}$ heterogenní nebo homogenní třídě, nezjistili u dětí čtyřletých a šestiletých významný rozdíl, u pětiletých dětí byl zjištěn rozdíl ve prospěch homogenní třídy. Ve všech skupinách dětí došlo ke zlepšení v porovnání výsledků testů na začátku a na konci školního roku, nezávisle na tom, zda byly zařazeny do heterogenní nebo homogenní tř́dy. Z toho autoři vyvozují, že na děti má pozitivní vliv účast v předškolním vzdělávání, že především díky předškolnímu vzdělávání se výsledky dětí zlepšují.

Mezi hlavní výsledky studie Huové et al. (2016), která byla zaměřena na zjišt’ování vlivu složení třídy na strategie emocionální regulace předškolních dětí ve vztahu ke způsobu vyjadřování emocí matky a vrstevníků, patří zjištění, že existuje závislost mezi projevy emocí u matek a jejich dětí. Zkoumané děti vyjadřovaly pozitivní emoce častěji než negativní. Děti zařazené do heterogenních tř́id byly častěji proaktivní při řešení vzniklých situací než děti zařazené do homogenních tříd. Současně děti čtyřleté, zařazené do heterogenních tříd, nejčastěji navrhovaly náhradní činnosti v komunikaci s ostatními dětmi. Výsledky této studie jsou však diskutabilní, i autoři sami na jisté limity upozorňují. Hlavní problém lze spatřit ve zvolené výzkumné metodě. Respondenti své emoce reportovali na základě dotazníku, což otvírá otázku po validitě a reliabilitě získaných dat. Rovněž porovnání charakteristik matek je do značné míry sporné. Skupina matek dětí zařazených do heterogenních tříd se reportovala jako emočně stabilní a pozitivně naladěné, skupina matek dětí zařazených do homogenních tř́d se popisovala spíše jako negativně zaměřené. Bližší vysvětlení však studie nenabízí.

Pro zodpovězení otázky, jaká je povaha výuky a učení se matematice v heterogenní třídě, využily autorky Woodová a Fridová (2005) kvalitativní př́stup. Rozvíjení matematických představ bylo zapracováno do vzdělávacího programu, využívaly se př́ílady a dětem známé situace z běžného života. Děti sdílely během úkolů své nápady, díky čemuž se učily z nápadů ostatních dětí. Pokud se ve skupině objevilo zkušenějšś a vyspělejší dítě, přebralo roli vedoucího či doučujícího. Učení bylo založeno na intersubjektivitě, tedy jejich společném porozumění aktivitě a jejímu cíli, přičemž starší děti pomáhaly mladším dětem. Autorky upozorňují, že děti si vzájemně pomáhají i v homogenních třídách, avšak v heterogenních jsou daleko větší rozdíly 
mezi dětmi, čímž je i vyšší efektivita sdílení mezi starším a mladším dítětem.

Intenzivní spolupráci mezi dětmi různého věku $\mathrm{v}$ heterogenní třídě sledovaly ve svém výzkumu i Bartonová a Baguleyová (2014). Cílem jejich výzkumu bylo posoudit, jakým způsobem se utvář́ skupina a jaká je její dynamika. Došly k závěrům, že heterogenní tř́ídy umožňují dětem maximální vývoj, pokud mohou pracovat ve skupině. S odkazem na další výzkum (Proehl et al., 2013) uvádějí, že společná zodpovědnost skupiny za výsledek vede $\mathrm{k}$ nižšímu výskytu rušivého chování a většímu respektu ke spolužákům.

Další oblast studí je věnována druhému významnému činiteli vstupujícímu do edukačního procesu v mateřské škole - osobnosti učitele (B). Cílem studií je analyzovat prŕpravnou činnost učitele a realizaci aktivit v různém uspořádání tř́dy. Ve studii Purtellové a Ansariové (2018) nebyla výzkumně prokázána žádná přímá spojitost mezi dosaženým vzděláním a délkou praxe učitele a zjištěnými výsledky v rozvoji dětí, ani problematickým chováním dětí a jejich sociálními dovednostmi. Autorky vycházejí z předpokladu, že učitelé s vyšším vzděláním a více zkušenostmi mohou být lépe vybaveni $\mathrm{k}$ vytváření pozitivního, přívětivého prostř̌edí $\mathrm{v}$ heterogenní třídě. Realizace aktivit $\mathrm{v}$ heterogenní třídě je náročnější, protože vzdělávací aktivity musí být přizpůsobené různým věkovým skupinám. Vyžaduje to od učitele velmi dobré organizační schopnosti a znalost složení dané skupiny, aby mohl zohledňovat individuální zvláštnosti jednotlivých dětí a přizpůsobovat jim dané úkoly. Vyšší vzdělání učitele může také zmírnit případné negativní dopady díky schopnosti učitele lépe strukturovat prostředí třídy tak, aby bylo přínosné pro mladší i starší děti. Různý typ aktivit a další učitelem ovlivněné atributy mohou měnit způsob, jakým heterogenní třída ovlivňuje rozvoj dětí. Matematické znalosti dětí však nezávisle na vzdělání učitele a kvalitě třídy byly ve výzkumu zjištěny nižší, pokud bylo ve třídě více tříletých dětí. Jedním z důvodů, které z výzkumu vyplývají, může být menší zaměření mateřských škol na matematickou pregramotnost dětí než na jejich čtenářskou pregramotnost a rozvoj jazyka.

Po zavedení organizačních změn do tureckého vzdělávacího systému si Ertürk-Karaová (2018) kladla otázku, jak vnímají heterogenní a homogenní uspořádání tř́d učitelé mateřských a základních škol a jak jsou připraveni na jejich vedení. Pouze dvě z deseti učitelek mateřských škol a jedna z deseti učitelek základních škol se vyjádřily pozitivně o svém působení v heterogenní tř́́dě. Ostatní názory byly negativní. Za negativa zavedení heterogenních tř́íd považovaly hlavně nedostatečnou pedagogickou podporu učitelů. Mezi další argumenty patřila organizační náročnost (mladší děti jsou pomalejší, je třeba jim připravit zvláštní úkoly, jsou snadno unavitelné, pozornost udrží kratší dobu a vyžadují od učitele více pozornosti, ve třídě se staršími ztrácejí sebevědomí) a komunikační problémy mezi dětmi různého věku (mladší se 
neumí vyjádřit, neumí se zapojit, neumí se bránit). Pokud bychom tyto argumenty shrnuli, nejedná se o negativní vliv heterogenních tříd na vývoj dětí, ale spíše o větší náročnost na činnost učitele.

Mezi faktory významně ovlivňující kvalitu vzdělávání v mateřské škole patří učitelovy komunikační dovednosti. Jednou z těchto dovedností je i vnímavost učitele $\mathrm{k}$ emočnímu nastavení dítěte a jeho myšlenkovým procesům. Helmerhorstová et al. (2019) realizovali výzkum, ve kterém zjišt'ovali míru učitelovy všímavosti $\mathrm{k}$ mysli dětí ve vztahu k různým proměnným: vzdělání učitele, délka praxe, počet dětí na učitele, věkové uspořádání tř́ídy. $Z$ výzkumu vyplývá, že v průměru $10 \%$ učitelských promluv a souvisejících komentářů odkazovalo $\mathrm{k}$ pocitům dětí, jejich myšlenkám a tužbám. Individuálně zaměřených komentářu pronesli zkoumaní učitelé nejvíce ve skupině dětí 0-2letých, zatímco skupinově zaměřených komentářủ bylo více u starších dětí a ve smíšené třídě. Více individuálně zaměřených komentářru bylo u méně početných skupin dětí a více skupinově zaměřených u vícepočetných skupin dětí.

Výzkumná pozornost je věnována rovněž zjišt’ování názorů rodičů na zařazení jejich dítěte do třídy s heterogenním nebo homogenním uspořádáním (C). Ve výzkumu Baileye et al. (2016) byl sledován pohled učitele mateřské školy současně s názorem rodičů na zařazení jejich dítěte do heterogenní či homogenní třídy. Na uspořádání tř́ídy mủže jinak pohlížet učitel a jinak rodiče. Jedná se zejména o př́pady, kdy do mateřské školy nastupuje mladší sourozenec společně se starším, což může ulehčit adaptaci na mateřskou školu nejen mladšímu sourozenci, ale i rodičům. To je jeden z významných důvodů, pro který rodiče převážně podporují zařazení svých dětí do heterogenní třídy. Podle rodičů mají děti v takovém uspořádání mateřskou školu raději a dosahují rovněž lepších výsledkủ (Bailey et al., 2016). Jedním z hlavních závěrů výzkumu je zjištění, že pro zavedení heterogenních tř́íd na jakkoli velkých školách je důležitá podpora učitelů ze strany rodičů i vedení, podpora rodičů při zapojení do vzdělávání jejich dětí, poskytování informací rodičům (zejména je poučit o tom, co mohou heterogenní tř́ídy dětem nabídnout), poskytnutí adekvátního, specificky zaměřeného vzdělání učitelům.

Na premise, že smíšené tř́dy zrcadlí rodinný život a umožňují sourozencům být spolu i mimo domov, staví výzkum Teszenyiové a Heveyové (2015). Dotazníkovým šetřením se pokusily zjistit klíčové faktory ovlivňující rodiče při výběru mateřské školy a dozvědět se, jak jsou rodiče spokojeni s vybraným typem skupiny. Hlavními motivy rodičů při vybírání mateřské školy pro své dítě byla poloha a vzdálenost školy od bydliště, zahrada školy, vzdělávací program a osobní doporučení. Věkové uspořádání třídy bylo rozhodujícím faktorem pouze pro $17 \%$ dotazovaných rodičů. Nejčastěji zmiňovanou výhodou smíšených tříd bylo, že se mladší děti učí od starších, avšak zmíněn 
byl i fakt, že se od nich mohou učit i nežádoucí způsoby chování. Rodiče považovali homogenní třídy za vhodnější k prrípravě na školu. Opakujícím se rysem komentářù rodičů z obou skupin bylo, že se výhody a nevýhody mění s věkem dětí - výhody smíšených tříd pro mladší děti byly často vyvažovány nevýhodami pro děti starší.

V několika studiích byly sledovány intervence prostřednictvím specifických programů různé povahy, působící změny v osobnostním rozvoji dítěte nebo v profesní zdatnosti učitele mateřské školy (D). Podnětné poznatky ke vztahu mezi věkovým složením dětí v heterogenní třídě, některými demografickými charakteristikami (mateřský jazyk dítěte, etnická př́islušnost, pohlaví) a úrovní školní zralosti dětí zařazených do programu Head Start přinesl výzkum Bellové et al. (2013). V oblasti učení výzkum ukázal, že starší děti dosáhly během jednoho roku většího zlepšení než mladší děti. Ty naopak prokázaly větší nárůst v sociálních a emocionálních dovednostech. Starší děti ve třídách s širší věkovou kompozicí třídy byly učiteli hodnoceny lépe než děti ze tříd s menší variabilitou, mladší děti v těchto třídách projevily lepší př́istup k učení. Zjištění z výzkumu Hsuehové et al. (2014) umožnila porovnat efektivitu tř́ vzdělávacích programů realizovaných v USA zaměřených na socioemoční rozvoj dětí: The Incredible Years, PATH a Mind-play. $\mathrm{Z}$ jejich závěrů vyplynulo, že program The Incredible Years je vzhledem ke svému behaviorálnímu zaměření tř́letým dětem pravděpodobně př́ístupnější než další dva programy (program PATH a program Mind-play). Program The Incredible Years měl pozitivní vliv na sociální chování (kooperaci, sebekontrolu, blízkost s učitelem, prosazování), ale neměl významný vliv na celkové klima trrídy, na problémové chování, interpersonální dovednosti nebo konflikty s učitelem. Přestože autoři nabádají k opatrnosti př́i interpretaci výsledků vzhledem $\mathrm{k}$ možné zaujatosti učitelů, zaznamenali statisticky významný rozdíl při porovnání s kontrolní skupinou v předškolních dovednostech (obecné znalosti, jazyk a gramotnosti, matematické myšlení). Ačkoli i ve zbývajících dvou programech došlo ke změnám v učitelově př́stupu, nebyl u nich zaznamenán významný rozdíl ve změně klimatu třídy. Program My Teaching Partner (MTP) určený k profesnímu rozvoji učitelů mateřských škol byl analyzován a jeho vliv na rozvoj dětí byl sledován ve studii Ansariové a Pianty (2018). Zjistilo se, že tento program koučinkové intervence byl efektivnější pouze za určitých podmínek, a to když učitel působil ve tř́ídě méně věkově smíšené, tedy když ve tř́dě převažovaly čtyřleté děti. Menší efekt mělo, pokud ve třídě byla větší diverzita složení, nezávisle na tom, zda bylo ve třídě více mladších dětí nebo více dětí starších. Jeden ze závěrů, který z výzkumu vyplývá, směřuje k požadavku zaměřit profesní vzdělávání učitelů mateřských škol na výzvy, které přináší věková heterogenita tř́dy. 


\section{Shrnutí a diskuse}

V následujícím textu nabízíme shrnutí výsledků vybraných zahraničních empirických studií a diskusi jejich zjištění v širších souvislostech.

Více než polovina studií zahrnutých v našem přehledu se věnovala vlivu heterogenního a homogenního uspořádání tříd na rozvoj dítěte, at' již v kognitivní či socioemoční oblasti. Výsledky studií ukázaly, že heterogenní uspořádání tříd má potenciál pro optimální rozvoj dítěte v těchto oblastech. ${ }^{5}$ Výsledky dokresluji teoretické předpoklady Piageta (in Harmon, 2001), Vygotského (1978) i Bandury (1986) o vlivu různé vývojové úrovně dětí a interakcí různě starých dětí na jejich vývoj. Potvrzují tak, že úmyslné seskupování dětí různého věku podporuje efektivnější vzdělávání a vyšší úroveň dosažených výsledků (Blasco et al., 1993; Kasten \& Clarke, 1993; McClellan \& Kinsey, 1994; Rathbon, 1993; Slavin, 1987; Whiting, 1983).

Tato pozitiva však nebyla prokázána ve všech studiích. Některé zmiňují horší výsledky dětí v heterogenních třídách než v homogenních. V diskusích však autoři poukazují na možnost, že horší výsledky byly způsobeny nepřipraveností učitelů na práci s heterogenitou a jejich tendenci přizpůsobovat náročnost činností nejslabší skupině (Ansari, 2017; Ansari \& Pianta, 2018; Ansari \& Purtell, 2018; Ertürk-Kara, 2018). K obdobným závěrům došly také autorky studií zkoumajících tuto problematiku v českém prostředí (Havlová, 2012; Luňáková, 2008; Sajbotová, 2016; Svobodová, 2011; Šprachtová, 2015). Také některé starší zahraniční výzkumy (Mason \& Burns, 1996; Urberg \& Kaplan, 1986) uvádějí, že děti v heterogenní třídě vykazovaly menší pokroky v raném učení a vývoji, protože jim učitelé poskytovali méně podnětný obsah. To mohlo být způsobeno tím, že se museli přizpůsobit širší škále úrovní znalostí dětí, což mohlo vést ke stagnaci ve vývoji starších a kognitivně vyspělejších dětí. Tyto závěry korespondují se zjištěními Katzové et al. (1990), že věkově heterogenní třídy nejsou samy o sobě zárukou lepších kognitivních a socioemočních výsledků v rozvoji dítěte. Zajišt'ují spíše lepší podmínky pro výměnu zkušeností mezi staršími a mladšími dětmi, které musí být podpořeny vhodnými strategiemi vzdělávání ze strany učitele.

Tato zjištění lze podpořit i poznatky dalších autorů, z nichž vyplývá, že čím více času trávily děti v aktivitách kvalitně didakticky řízených učitelem, tím lepší byly jejich výsledky (např. Barnett, 2011; Mashburn et al., 2009; Pianta et al., 2008). Z toho můžeme usuzovat, že vysoká úroveň didaktických

$\mathrm{V}$ představených studiích autoři neuváděli údaj o tom, kolik dětí bývá zařazeno do třídy a kolik dětí připadá na učitele. Tato proměnná přitom může mít výrazný vliv na výsledky výzkumů. 
dovedností učitele a znalost práce s heterogenní skupinou může ještě více posílit pozitivní dopady různorodého prostředí na učení a rozvoj dětí. Některé výzkumy poukazují na to, že pozitivní dopady heterogenního uspořádání mohou přispívat $\mathrm{k}$ rozvoji dětí, jen když jsou spojeny s vysoce kvalitními vzájemnými interakcemi mezi učitelem a dítětem, což je v souladu i s výzkumy dalších autorů (např. Guo et al., 2014).

$\mathrm{Na}$ vliv učitelovy profesní kvality, ale také jeho přesvědčení o pozitivním vlivu heterogenity tř́́dy na rozvoj dětí lze usuzovat také ze zjištění studií zaměřených na názory učitelů. Zkoumaní učitelé se vyjadřovali k vysoké náročnosti prŕípravy podpůrného prostředí heterogenní třídy, plynoucí z př́itomnosti dětí různého věku a rozdílného stupně vývoje (např. Ertürk-Kara, 2018). I tyto studie navazují na zjištění dalších výzkumưo (např. Broome, 2009; Grove \& Fisher, 2006; Hitz et al., 2007; Tobin \& McInnes, 2008), v nichž autoři popisují heterogenní tř́idy jako prostředí poskytující př́íznivější rámec pro rozvoj efektivity činností ve třídě, emoční stability a diferencované výuky.

Z této premisy vycházejí některé české i zahraniční vzdělávací programy (např. Havlínová et al., 2000, 2006, 2008; Webster-Stratton, 2012), které považují heterogenitu a sociální učení za důležitý aspekt rozvoje socioemočních dovedností. Tyto programy a empirické nálezy představených výzkumů by se mohly stát východiskem pro bádání v oblasti heterogenity také v českém prostředí předškolního vzdělávání s cílem podpořit hlubší porozumění sociokonstruktivistickým př́stupům při vzdělávání dětí předškolního věku $\mathrm{v}$ českých mateřských školách.

Jen malá část analyzovaných studií věnovala pozornost názorům rodičů na zařazení jejich dítěte do heterogenní třídy. Výzkum Teszenyiové a Heveyové (2015) odhalil, že zařazení dítěte do heterogenní třídy je pro rodiče méně významným faktorem při rozhodování o výběru mateřské školy. České výzkumy se $\mathrm{v}$ rámci problematiky heterogenního a homogenního uspořádání tříd zaměřovaly na názory rodičů častěji. $V$ názorech rodičů převládá pocit, že jsou homogenní tř́́dy lepši pro přípravu dětí na nástup do školy (Pincová, 2004; Sajbotová, 2016). Šprachtová (2015) se domnívá, že tato tvrzení vychází především z nedostatečné informovanosti. S názory rodičů na nevhodnost heterogenního uspořádání třídy z hlediska př́pravy na školu souzní také převládající názory učitelů, kteří se domnívají, že v homogenní třídě může celá skupina pracovat ve stejný čas a času je tak relativně více (Kramulová, 2015; Křŕžková, 2019).

V těchto výzkumech nebylo hlavním cílem zkoumat vliv heterogenního uspořádání tř́d na aspekty výuky v mateřských školách, proto nebyly zařazeny mezi analyzované studie. 


\section{Závěr}

Přehled zahraničních výzkumů naznačuje, že heterogenní uspořádání tříd podporuje jak kognitivní, tak socioemoční rozvoj dětí (sledovaná oblast cílů A). Je však nutné, aby učitelé vykazovali vysokou kvalitu v didaktických a komunikačních dovednostech podporujících učení dětí s různorodou úrovní znalostí, dovedností a schopností. Pro mladší děti se heterogenní třídy jeví jako vhodné prostředí pro jejich rychlou a úspěšnou adaptaci, starší děti pak často vystupují v roli učitelů a mladším dětem radí a pomáhají, což může podporovat vrstevnické učení. Pro učitele (sledovaná oblast cílů B) je heterogenní uspořádání tř́d náročné na př́pravu činností tak, aby respektovali individuální př́stup k dětem. Pro rodiče (sledovaná oblast cílů C) není heterogenita tř́d hlavním kritériem výběru mateřské školy, pro děti předškolního věku by ale častěji volili homogenní třídy.

V českém vzdělávacím prostředí nacházíme nejednotný názor na význam a efektivitu jednoho či druhého uspořádání tř̌́d mateřských škol, což je způsobeno minimem relevantních výzkumů.

Pro Českou republiku bylo dlouhé roky, zejména ve 2. polovině 20. století, typické spíše věkově homogenní uspořádání tř̌íd v souladu s Programem výchovné práce pro jesle a mateřrsé šooly (1984), který vycházel z vývojových specifik rozvoje dětí předškolního věku. Lze se domnívat, že požadavky RVP PV na vyvážený kognitivní a socioemoční rozvoj (RVP PV, 2004, 2018) přinesly na začátku nového tisíciletí vyšší počet heterogenních tříd. Z převládajícího názoru na nevhodnost heterogenních tř́d $z$ hlediska připravenosti dětí na vstup do základní školy lze usuzovat na dlouhotrvající vliv Programu výchovné práce pro jesle a mateřské školy (1984). Lze se domnívat, že mimo jiné stále dominuje důraz kladený na rozvoj kognitivních schopností, který podpořil také nově uzákoněný poslední povinný rok předškolního vzdělávání (2017).

Z výše uvedeného vyplývá, že by bylo vhodné zabývat se otázkou efektivity heterogenních a homogenních tř́id $\mathrm{v}$ českém prostředí výzkumně. Výzkumná zjištění by mohla přinést relevantní informace určené pro učitele mateřských škol, ale také pro př́pravné vzdělávání učitelů. Pro kvalitu profesního výkonu ve věkově smíšených tř́íách by pomohlo identifikovat didaktické aspekty a interakce, které podněcují sdílení zkušeností s učením a vytvářením jedinečné (individuální) struktury znalostí, jak naznačují konstruktivistické př́stupy přijaté kurikulární reformou. 


\section{Literatura}

Ansari, A. (2017). Multigrade kindergarten classrooms and children's academic achievement, executive function, and socioemotional development. Infant \& Child Development, 26(6), 2-19. http://doi.org/10.1002/icd.2036

Ansari, A., \& Pianta, R. C. (2018). Quarterly effects of an early childhood educator coaching intervention on preschoolers: The role of classroom age composition. Early Childhood Research Quarterly, 44, 101-113. https://doi.org/10.1016/j.ecresq.2018.03.001

Ansari, A., \& Purtell, K. M. (2018). Continuity and changes in classroom age composition and achievement in Head Start. Journal of Applied Developmental Psychology, 58, 86-95. https:// doi.org/10.1016/j.appdev.2018.07.002

Bacharach, N., Hass len, R. C., \& Anderson, J. (1995). Learning together: A manual for multiage grouping. Corwin Press.

Bailey, G. J., Werth, E. P., Allen, D. N., \& Sutherland, L. L. (2016). The Prairie Valley project: Reactions to a transition to a school wide, multiage elementary classroom design. School Community Journal, 26(1), 239-264.

Bandura, A. (1986). Social foundations of thought and action: A social cognitive theory. Prentice Hall.

Barnett, W. S. (2011). Effectiveness of early educational intervention. Science, 333, 975-978. https://doi.org/10.1126/science.1204534

Barton, G., \& Baguley, B. (2014). Learning through story: A collaborative, multimodal arts approach. English Teaching: Practice and Critique, 13(2), 93-112.

Bell, E. R., Greenfield, D. B., \& Bulotsky-Shearer, R. J. (2013). Classroom age composition and rates of change in school readiness for children enrolled in Head Start. Early Childhood Research Quarterly, 28(1), 1-10. https://doi.org/10.1016/j.ecresq.2012.06.002

Blackmore, L. (1996). Multiage/non-graded education: From practice to theory [Videotape]. Linton Professional Development Corporation, Video Journal of Education.

Blasco, P. M., Bailey, D. B., Jr., \& Burchinal, M. A. (1993). Dimensions of mastery in sameage and mixed-age integrated classrooms. Early Childhood Research Quarterly, 8(2), 193-206. https://doi.org/10.1016/S0885-2006(05)80090-0

Bredekamp, S. (Ed.). (1987). Developmentally appropriate practice in early childhood programs serving children from birth through age 8. National Association for the Education of Young Children.

Broome, J. L. (2009). A descriptive study of multi-age art education. Studies in Art Education: A Journal of Issues and Research, 50(2), 167-183. https://doi.org/10.1080/00393541.2009.115 18764

Brown, A., \& Palinscar, A. (1986). Guided, cooperative learning and individual knowledge acquisition. Technical Report No. 372. https://files.eric.ed.gov/fulltext/ED270738.pdf

Bruner, J. S. (1978). The role of dialogue in language acquisition. In A. Sinclair, R. J. Jarvelle, \& W. J. M. Levelt (Eds.), The child's concept of language. Springer-Verlag.

Cascio, E., \& Whitmore Schanzenbach, D. W. (2007). First in the class? Age and the education production function. Education Finance and Policy, 11(3), 225-250. https://doi.org/10.3386/ w13663

Edwards, C., Gandini, L., \& Forman, G. (2012). The hundred languages of children: The ReggioEmilia experience in transformation. Praeger.

Ermeling, B. A. (2010). Tracing the effects of teacher inquiry on classroom practice. Teaching and Teacher Education, 26(3), 377-388. https://doi.org/10.1016/j.tate.2009.02.019 
Ertürk-Kara, H. G. (2018). Primary and kindergarten teachers' opinions on mixed age grouping education. Journal of Theoretical Educational Science, 11(2), 279-295. https://doi. org/10.30831/akukeg. 355337

Gerde, H. K., Schachter, R. E., \& Wasik, B. A. (2013). Using the scientific method to guide learning: An integrated approach to early childhood curriculum. Early Childhood Education, 41, 315-323. https://doi.org/10.1007/s10643-013-0579-4

Goodlad, J. I., \& Anderson, R. H. (1987). The nongraded elementary school. Teachers College Press.

Grove, K., \& Fisher, D. (2006). ,Doing collaboration': The process of constructing an educational community in an urban elementary school. Ethnography and Education, 1(1), 53-66. https://doi.org/10.1080/17457820500512770

Guo, Y., Tompkins, V., Justice, L., \& Petscher, Y. (2014). Classroom age composition and vocabulary development among at-risk preschoolers. Early Education and Development, 25(7), 1016-1034. https://doi.org/10.1080/10409289.2014.893759

Harmon, M. (2001). Comparison of the academic achievements of primary school children in multiage and traditional classrooms [Unpublished disertation theses]. East Tennessee State University.

Havlínová, M. (Ed.) (1995). Zdravá mateřská škola. Portál.

Havlínová, M., Lacinová, I., Petrasová, N., Syslová, Z., Šprachtová, L., \& Vencálková, E. (2000). Kurikulum podpory zdravi v mateřské škole. Portál.

Havlínová, M., Lacinová, I., Petrasová, N., Syslová, Z., Šprachtová, L., \& Vencálková, E. (2006). Kurikulum podpory zdravi v mateřské škole (2. vydání). Portál.

Havlínová, M., Lacinová, I., Petrasová, N., Syslová, Z., Šprachtová, L., \& Vencálková, E. (2008). Kurikulum podpory zdravi v mateřské škole (3. vydání). Portál.

Havlová, J. (2012). Výhody či nevýhody věkově smíšených skupin? Poradce reditelky mateřské skooly, 2(1), 20-22.

Helmerhorst, K. O. W., Colonnesi, C., \& Fukkink, R. G. (2019). Caregiver's mind-mindedness in early center-based childcare. Early Education and Development, 30(7), 854-871. https:// doi.org/10.1080/10409289.2019.1593076

Hitz, M. M., Somers, M. C., \& Jenlink, C. L. (2007). The looping classroom: Benefits for children, families, and teachers. Young Children, 62(2), 80-84.

Hsueh, J. A., Lowenstein, E., Morris, P., Mattera, S. K., \& Bangser, M. (2014). Impacts of socialemotional curricula on three-year-olds: Exploratory findings from the Head Start CARES. Demonstration. OPRE Report 2014-78. https://www.mdrc.org/sites/default/files/Head\%20Start \%20 CARES\%203s\%20Report $\% 202014$.pdf

Hu, Y., Wang, Y., \& Liu, A. (2016). The influence of mothers' emotional expressivity and class grouping on Chinese preschoolers' emotional regulation strategies. Journal of Child and Family Studies, 26(3), 824-832. https://doi.org/10.1007/s10826-016-0606-3

Inhelder, B., \& Piaget, J. (1958). The growth of logical thinking from childhood to adolescence. Basic Books.

Kasten, W., \& Clarke, B. K. (1993). The multi-age classroom: A family of learners. Richard C. Owen. Publishers, Inc.

Katz, L. G., Evangelou, D., \& Hartman, J. A. (1990). The case for mixed-agegrouping in early education. National Association for the Education of Young Children.

Kot’átková, S. (2014). Díté a mateřské š̉kola: co by měli rodiče znát, učitelé respektovat a rozvíjet. Grada.

Kramulová, D. (2015). Heterogenní třídy: pro a proti. Informatorium 3-8, 5.

Křrižková, P. (2019). Socializace prédškolnich dětí v homogenni a heterogenni skupiněv MŠ. [Bakalářská práce, Jihočeská univerzita v Českých Budějovicích]. Theses.cz. https://theses.cz/id/q13996/ 
Lanphear, J. (2016). Inquiry and intersubjectivity in a Reggio Emilia-inspired preschool. Journal of Research in Childhood Education, 31(4), 597-614. https://doi.org/10.1080/02568543 .2017 .1348412

Lunáková, J. (2008). Význam věkovè heterogennich trúd v mateř̌ké škole pro rozvoj dètti [Bakalářská práce, Jihočeská univerzita v Českých Budějovicích]. Theses.cz. https://theses.cz/id/xrhi6h/

Mareš, J. (2013). Přehledové studie: jejich typologie, funkce a způsob vytváření. Pedagogická orientace, 23(4), 427-454. https://doi.org/10.5817/PedOr2013-4-427

Mashburn, A. J., Justice, L. M., Downer, J. T., \& Pianta, R. C. (2009). Peer effects on children's language achievement during pre-kindergarten. Child Development, 80(3), 686-702. https:// doi.org/10.1111/j.1467-8624.2009.01291.x

Mason, D. A., \& Burns, R. B. (1996). "Simply no worse and simply no better" may simply be wrong: A critique of Veenman's conclusion about multigrade classes. Review of Educational Research, 66(3), 307-322. https://doi.org/10.3102/00346543066003307

McClellan, D. E., \& Kinsey, S. J. (1994). Multiage grouping: Implications for education. In P. Chase \& J. Doan (Eds.), Full circle: A new look at multiage education (s. 147-165). Heinemann.

Miller, B. (1994). Children at the centre: Implementing the multiage classroom. Northwest Regional Educational Laboratory.

National Association for the Education of Young Children [NAEYC]. (1987). Position statement on quality, compensation, and affordability. Young Children, 43(1), 1-4.

Okutan, S., Tepeli, K., Tugrul, B., \& Gunes, G. (2014). Preschool education in mixed- versus single-age groups: Effects on developmental characteristics of young children. In M. Yasar, J. Galbraith, \& O. Ozkan (Eds.), Contemporary perspectives and research on early childhood education (s. 373-383). Cambridge Scholars Publishing.

Pianta, R. C., Belsky, J., Vandergrift, N., Houts, R., \& Morrison, F. J. (2008). Classroom effects on children's achievement trajectories in elementary school. American Educational Research Journal, 45, 365-397. https://doi.org/10.3102/0002831207308230

Pincová, E. (2004). Heterogenní třídy v MŠ ano, či ne? Informatorium 3-8, 3.

Politano, C., \& Davies, A. (1994). Multiage and more - building connections. Pegasus Publishers.

Program výchouné práce pro jesle a mateŕské školy. (1984). SPN.

Proehl, R. A., Douglas, S., Elias, D., Johnson, A. H., \& Westsmith, W. (2013). A collaborative approach: Assessing the impact of multi-grade classrooms. Catholic Education: A Journal of Inquiry and Practice, 16(2), 417-440.

Průcha, J., Walterová, E., \& Mareš, J. (2013). Pedagogický slovník. Portál.

Př́ihoda, V. (1967). Ontogenese lidské psychiky. I. SPN.

Purtell, K. M., \& Ansari, A. (2018). Classroom age composition and preschoolers' school readiness: The implications of classroom quality and teacher qualifications. AERAOpen, 4(1), 86-95.

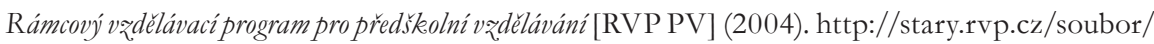
RVP_PV-2004.pdf

Rámcový vzdèlávaci program pro predškeolni vz̨éláváni [RVP PV] (2018). https://www.msmt.cz/ vzdelavani/predskolni-vzdelavani/ramcovy-vzdelavaci-program-pro-predskolnivzdelavani-od-1-1

Rathbone, C. (Ed.). (1993). Multi age portraits: Teaching and learning in mixed-age classrooms. Crystal Springs Books.

Reeve, R. A., \& Brown, A. L. (1985). Metacognition reconsidered: Implications for intervention research. Journal of Abnormal Child Psychology, 13(3), 343-356. 
Rice, J., \& Shortland-Jones, B. (1999). Planning and implementing multiage grouping in your school. WA Primary Principals Association.

Rogoff, B. (1990). Apprenticeship in thinking: Cognitive development in social context. Oxford University Press.

Sajbotová, M. (2016). Heterogenní, nebo bomogenni usporádáni dètské skupiny v materské škole? [Bakalářská práce]. Ostravská univerzita.

Slavin, R. E. (1987). Developmental and motivational perspectives on cooperative learning a reconciliation. Child Development, 58, 1161-1167. https://doi.org/10.2307/1130612

Srbová, V. (2011). Rozdíly homogenně a heterogennè uspoŕádaných tř́d v MŠ a jejich vliv na prípravenost ditéte pro vstup do 1. trúdy základni školy [Bakalářská práce, Univerzita Karlova]. Depozitár. http://hdl.handle.net/20.500.11956/35387.

Stone, S. (1998). Defining the multi-age classroom. ACEI Focus on Elementary Ages 7-10, 10(3), $1-6$.

Svobodová, M. (2011). Výhody věkově smišených tríd v mateřské škeole [Bakalářská práce, Masarykova univerzita]. Archiv závěrečných prací MUNI. https://is.muni.cz/th/dblm1/

Syslová, Z., Borkovcová, I., \& Průcha, J. (2014). Pécé a vądělávání v raném věku. Wolters Kluwer. Šprachtová, L. (2015). Věkově smíšené tř̌ídy dětem svědčí. Informatorium 3-8, 3.

Taguma, M., Litjens, I., \& Makowiecki, K. (2012). Quality matters in early childhood education and care: Czech Republic. OECD Publishing.

Tercek, M. P. (1997). Mixed-age grouping in kindergarten: A best case example of developmentally appropriate practice or Horace Mann's worst nightmare? Malone College.

Teszenyi, E., \& Hevey, D. (2015). Age group, location or pedagogue: Factors affecting parental choice of kindergartens in Hungary. Early Childhood Pedagogy, 158 (11-12), 1961-1977. https:// doi.org/10.1080/03004430.2015.1028391

Tobin, R., \& McInnes, A. (2008). Accommodating differences: Variations in differentiated literacy instruction in grade 2/3 classrooms. Literacy, 42(1), 3-9. https://doi.org/10.1111/ j.1467-9345.2008.00470.x

Urberg, K. A., \& Kaplan, M. G. (1986). Effects of classroom age composition on the play and social behaviors of preschool children. Journal Applied Developmental Psychology, 7(4), 403-415. https://doi.org/10.1016/0193-3973(86)90009-2

Veenman, S. (1996). Effects of multigrade and multi-age classes reconsidered. Review of Educational Research, 66(3), 323-340. https://doi.org/10.3102/00346543066003323

Velíšková, B. (2014). Věkově heterogenni versus věkově homogenni trídy v mateřské škole [Bakalářská práce, Jihočeská univerzita v Českých Budějovicích]. Theses.cz. https://theses.cz/id/3hqphb/

Vygotskij, L. S. (1978). Interaction between learning and development. In M. Cole, V. JohnSteiner, S. Scribner, \& E. Souberman (Eds.), Readings on the development of children (s. 34-41). Harvard University Press.

Webster-Stratton, C. (2012). Incredible teachers: Nurturing children's social, emotional, and academic competence. Incredible Years.

Whiting, B. B. (1983). The genesis of prosocial behavior. In D. L. Bridgeman (Ed.), The nature of prosocial development (s. 221-242). Academic Press.

Wood, K., \& Frid, S. (2005). Early childhood numeracy in a multiage setting. Mathematics Education Research Journal, 16(3), 80-99. https://doi.org/10.1007/BF03217402 


\section{Kontakty na autorky}

Zora Syslová

Pedagogická fakulta, Masarykova univerzita

E-mail: syslova@ped.muni.cz

Eva Nováková

Pedagogická fakulta, Masarykova univerzita

E-mail: novakova@ped.muni.cz

Veronika Najvarová

Pedagogická fakulta, Masarykova univerzita

E-mail: najvarova@ped.muni.cz

\section{Corresponding authors}

Zora Syslová

Faculty of Eucation, Masaryk University

E-mail: syslova@ped.muni.cz

Eva Nováková

Faculty of Eucation, Masaryk University

E-mail: novakova@ped.muni.cz

Veronika Najvarová

Faculty of Eucation, Masaryk University

E-mail: najvarova@ped.muni.cz 